\title{
Renal Metabolic Response to Acid-Base Changes
}

\author{
II. THE EARLY EFFECTS OF METABOLIC ACIDOSIS \\ ON RENAL METABOLISM IN THE RAT
}

\author{
George A. O. Alleyne \\ From the Medical Research Council, Tropical Metabolism Research Unit, \\ University of the West Indies, Mona, Kingston 7, Jamaica
}

\begin{abstract}
A в S T R A C T The early renal metabolic response was studied in rats made acidotic by oral feeding of ammonium chloride. $2 \mathrm{hr}$ after feeding of ammonium chloride there was already significant acidosis. Urinary ammonia also increased after ammonium chloride ingestion and at $1 \frac{1}{2} \mathrm{hr}$ was significantly elevated. In vitro gluconeogenesis by renal cortical slices was increased at $2 \mathrm{hr}$ and thereafter increased steadily. Ammonia production by the same slices was also increased at $2 \mathrm{hr}$, but thereafter fell and at $6 \mathrm{hr}$ had decreased to levels which, although higher than those of the control, were lower than those obtained from the rats acidotic for only $2 \mathrm{hr}$. There was no correlation between in vitro gluconeogenesis and ammonia production by kidney slices from rats during the first $6 \mathrm{hr}$ of acidosis, but after $48 \mathrm{hr}$ of ammonium chloride feeding, these two processes were significantly correlated. The early increase in renal gluconeogenesis was demonstrable with both glutamine and succinate as substrates.
\end{abstract}

The activity of the enzyme phosphoenolpyruvate carboxykinase was increased after $4-6 \mathrm{hr}$ of acidosis. During this time there was a decrease in renal RNA synthesis as shown by decreased uptake of orotic acid- ${ }^{3} \mathrm{H}$ into RNA.

Metabolic intermediates were also measured in quickfrozen kidneys at varying times after induction of acidosis. There was an immediate rise in aspartate and a fall in $\alpha$-ketoglutarate and malate levels. There was never any difference in pyruvate or lactate levels or lactate: pyruvate ratios between control and acidotic rats. Phosphoenolpyruvate rose significantly after $6 \mathrm{hr}$ of acidosis.

All the data indicate that increased gluconeogenesis is an early response to metabolic acidosis and will

This work was presented in part at the 4th International Congress of Nephrology, Stockholm, Sweden, May 1969.

Received for publication 10 November 1969 and in revised form 2 January 1970. facilitate ammonia production by utilization of glutamate which inhibits the glutaminase I enzyme. The pattern of change in metabolic intermediates can also be interpreted as showing that there is not only enhanced gluconeogenesis, but also that there may be significant increase of activity of glutaminase II as part of the very early response to metabolic acidosis.

\section{INTRODUCTION}

Urinary excretion of ammonia is essential for maintenance of normal acid-base homeostasis in several species including man, rat, and the dog, and it was demonstrated some 20 yr ago (1) that an increase in urinary ammonia is a typical response to metabolic acidosis. In spite of this, there is no agreement as to the early sequence of events following acidosis or the fundamental nature of the stimulus to the ammoniagenesis which occurs.

Previous reports from this laboratory have described the response of the rat kidney to metabolic acidosis of $48 \mathrm{hr}$ duration $(2,3)$. This consisted of certain changes in metabolic intermediates and significant increases in activity of the enzyme phosphoenolpyruvate carboxykinase (PEPCK). These changes were presented in the light of a close relationship between gluconeogenesis and ammonia production which has been postulated (4. 5 ) and we proposed that the control of the two processes lay at the conversion of oxaloacetate to phosphoenol pyruvate by the enzyme PEPCK. It was shown further that there was an increase in enzyme activity as early as $6 \mathrm{hr}$ after induction of metabolic acidosis.

The present experiments represent an attempt to examine the early events which occur in the kidney in response to ammonium chloride-induced acidosis. By measuring key metabolic intermediates, PEPCK activity, in vitro gluconeogenesis, and ammoniagenesis we can show a set of events which temporally are closely con- 
nected and perhaps indicate the way in which the rat increases ammonia production in response to an acid load.

The results show that urinary ammonia increases $1 \frac{1}{2}$ hr after $\mathrm{NH}_{4} \mathrm{Cl}$ is given orally, and renal cortical slices taken from rats fed $\mathrm{NH}_{4} \mathrm{Cl} 2 \mathrm{hr}$ previously, already show enhanced gluconeogenesis and ammoniagenesis, but the two processes are not as closely related as in the more chronically acidotic rats. It is suggested that activation of the glutaminase II system is also part of the early response to acidosis.

\section{METHODS}

Except where stated, all experiments were performed on male Sprague-Dawley or Wistar rats which weighed between 175 and $250 \mathrm{~g}$ and were previously fed on Purina Laboratory Chow (Ralston Purina Company, St. Louis, Mo.). There was no difference between the two strains in the metabolic response to acidosis.

Induction of acidosis. The rats were all deprived of solid food for $12 \mathrm{hr}$ before sacrifice and fed by stomach tube. The experimental group received $2.5 \mathrm{ml} / 100 \mathrm{~g}$ body weight of a $400 \mathrm{~mm}$ aqueous $\mathrm{NH}_{4} \mathrm{Cl}$ solution and rats were sacrificed at 2 , 4 , or $6 \mathrm{hr}$ later. Controls received an equal volume of water. In the experiments in which acidosis was continued for $48 \mathrm{hr}$, the feeding protocol was as described previously (3). In most experiments, control and acidotic rats were sacrificed simultaneously.

Anesthetic. Sodium pentobarbital $40 \mathrm{mg} / \mathrm{kg}$ body weight was used routinely. When blood was needed, it was withdrawn into heparinized syringes from the exposed abdominal aorta.

Ammonia excretion. Four female rats (160-180 g) were anesthetized with sodium pentobarbital $20 \mathrm{mg} / \mathrm{kg}$ body weight and the bladder was catheterized. Small quantities of pentobarbital were given as required to maintain light anesthesia. Urine was collected for periods of $30 \mathrm{~min}$ and at the end of the collection period the bladder was emptied by manual compression and washed twice with $0.5 \mathrm{ml}$ aliquots of $0.9 \% \mathrm{NaCl}$ and once with $0.5 \mathrm{ml}$ of air. The urine and washings were adjusted to a volume of $5.0 \mathrm{ml}$ for measurement of ammonia. After two control periods the rats received by stomach tube $1.25 \mathrm{ml} / 100 \mathrm{~g}$ body weight of a $800 \mathrm{~mm}$ aqueous $\mathrm{NH}_{4} \mathrm{Cl}$ solution. Urine collection was then continued for $4 \mathrm{hr}$.

In vitro gluconeogenesis. Slices of kidney cortex were cut by hand by the method of Deutch (6) and washed in cold $0.9 \% \mathrm{NaCl}$. Portions of slices which yielded $4-10 \mathrm{mg}$ dry weight were placed in $50-\mathrm{ml}$ conical flasks which contained $5.0 \mathrm{ml}$ of Krebs-Ringer bicarbonate buffer with the appropriate substrate and which had previously been gassed with $95 \% \mathrm{O}_{2}$ and $5 \% \quad \mathrm{CO}_{2}$. The flasks were quickly stoppered and flushed with the same gas mixture. Incubation was carried out for $1 \mathrm{hr}$ at $37^{\circ} \mathrm{C}$ in a metabolic bath which oscillated at $100 / \mathrm{min}$; at the end of incubation, flasks were removed and slices taken out and placed into tared tubes for drying at $100^{\circ} \mathrm{C}$ for $4 \mathrm{hr}$. Glucose and ammonia were measured in aliquots of the medium. The $\mathrm{pH}$ of the medium was 7.35-7.42 and did not change significantly during incubation. Net glucose or net ammonia production refers to the glucose or ammonia produced in the presence of substrate minus glucose or ammonia produced in identically treated flasks which contained no substrate.
Orotic acid-s ${ }^{3} H$ injections. The uptake of orotic acid- ${ }^{3} \mathrm{H}$ into the total RNA of kidney cortex was used as a measure of RNA synthesis. $20 \mu \mathrm{Ci}$ of orotic acid- ${ }^{3} \mathrm{H}-0.2 \mathrm{ml}$ of a solution with a specific activity of $1 \mathrm{Ci} / \mathrm{mm}$-was given by intraperitoneal injection $2 \mathrm{hr}$ before sacrifice; therefore, in the rats acidotic for $2 \mathrm{hr}, \mathrm{NH}_{4} \mathrm{Cl}$ and orotic acid had to be given simultaneously.

Metabolic intermediates. Rats were anesthetized at the appropriate times and kidneys were rapidly removed and crushed in a stainless steel mortar which contained liquid air. The powdered frozen kidney was homogenized in $6 \%$ perchloric acid in a Jencons glass homogenizer with a Teflon pestle (Jencons, Hemel Hempstead, England). The protein.free supernatant remaining after centrifuging was neutralized with $5 \mathrm{M} \mathrm{K}_{2} \mathrm{CO}_{3}$ in the standard manner (7). The protein precipitate was dissolved in $2.0 \mathrm{~N} \mathrm{NaOH}$.

Assays.-Blood $\mathrm{pH}$ was measured with a Radiometer micro Astrup assembly (Copenhagen, Denmark). Plasma $\mathrm{CO}_{2}$ was measured with a Natelson micro gasometer (Scientific Industries Inc., Springfield, Mass.). The RNA and DNA in kidney cortex were extracted and measured by methods described by Munro and Fleck (8).

Metabolic intermediates were all measured spectrophotometrically by standard enzymatic methods (7) which employed NADH oxidation or NAD reduction. For measurement of malate, the acetyl pyridine analogue of NAD was used. Pyruvate was always measured within $6 \mathrm{hr}$ of sacrifice of the animals. Phosphoenolpyruvate carboxykinase (PEPCK) was measured in kidney cortex by two methods. The decarboxylation of oxaloacetate was as described by Nordlie and Lardy (9) and the bicarbonate ${ }^{14} \mathrm{C}$ exchange assay was that of Chang and Lane (10). For the decarboxylation assay, slices of kidney cortex were homogenized in ice-cold $0.25 \mathrm{~m}$ glucose, and the resultant homogenate centrifuged at $78,000 \mathrm{~g}$ in a Beckman model L preparative ultracentrifuge for $2 \mathrm{hr}$ (Beckman Instruments, Inc., Ful. lerton, Calif.). The supernatant solution was used for the assay. For the bicarbonate exchange, the homogenate was centrifuged at approximately $5000 \mathrm{~g}$ for $30 \mathrm{~min}$ to remove the mitochondria and nuclei, and the supernatant was used. Protein was measured by the method of Lowry, Roseborough, Farr, and Randall (11). Ammonia was measured colorimetrically (12). Glucose was measured by the specific glucose oxidase method (13).

Counting of radioactivity. The $\mathrm{RNA}^{-3} \mathrm{H}$ and the ${ }^{14} \mathrm{C}$ labeled malate in the bicarbonate exchange assay of PEPCK were counted in a Beckman L.S. 150 liquid scintillation counter with external standard channels ratio. The scintillant was $0.6 \%$ PPO (2,5-diphenyloxazole) in a toluene: Triton $\mathrm{X}(2: 1)$ mixture.

\section{RESULTS}

Acid-base status (Table I). Oral $\mathrm{NH}_{4} \mathrm{Cl}$ produced a significant degree of metabolic acidosis which was maximal at $2 \mathrm{hr}$. (Throughout this paper, the statement that differences between means are significant indicates a $P$ value of at least 0.05 as determined by Student's $t$ test.) There was a rise in blood hydrogen ion concentration and a fall in plasma $\mathrm{CO}_{2}$. At 4 and $6 \mathrm{hr}$ after the $\mathrm{NH}_{4} \mathrm{Cl}$, the acidosis was less severe. Similar data for rats acidotic for $48 \mathrm{hr}$ have been reported previously (3). 
Ammonia excretion (Fig. 1). This shows that after an intragastric acid load, urinary ammonia started to rise and at $1 \frac{1}{2} \mathrm{hr}$ was already significantly higher than control values. The ammonia excretion appeared to plateau between 2 and $4 \mathrm{hr}$.

In vitro gluconeogenesis and ammoniagenesis. Rats were sacrificed at the indicated times after induction of metabolic acidosis. With $10 \mathrm{~mm}$ glutamine as substrate (Table II) there was increased gluconeogenesis after $2 \mathrm{hr}$ of acidosis. There was no significant difference in gluconeogenesis in kidneys from rats sacrificed at 2 and $4 \mathrm{hr}$, but apart from this, there was a steady increase in gluconeogenic capacity and after $48 \mathrm{hr}$ of acid feeding gluconeogenesis was twice the control values. For the 48 -hr studies, rats were fed $\mathrm{NH}_{4} \mathrm{Cl}$ in glucose every 12 $\mathrm{hr}$ so renal gluconeogenesis was measured in a group of control rats fed only glucose for $48 \mathrm{hr}$. Their net glucose production was $75.5 \pm 2.8 \mu \mathrm{mole} / \mathrm{g}$ dry weight per $\mathrm{hr}$ (mean \pm sEM, $n=7$ ). This value is not different from the control values in Table II which were from rats given only water once by stomach tube.

In vitro ammonia production is shown in Table III. There was a significant increase in ammonia production from rats acidotic for only $2 \mathrm{hr}$. However, in contrast with the gluconeogenesis data, there was a subsequent decrease in ammonia production, and the value for rats acidotic for $6 \mathrm{hr}$, although higher than the control value is significantly lower than that obtained in rats acidotic for 2 or $4 \mathrm{hr}$. After $48 \mathrm{hr}$ of acidosis, ammonia production from cortical slices had risen again and was significantly higher than that at $6 \mathrm{hr}$ but still not higher than that at $2 \mathrm{hr}$.

An attempt was made to correlate gluconeogenesis and ammonia production from cortical slices. There was
TABLE I

Blood Hydrogen Ion Concentration and Plasma $\mathrm{CO}_{2}$ in Rats at Varying Times after Feeding

\begin{tabular}{cccc}
\hline Time & Group & Blood $\mathrm{H}$ & Plasma CO \\
\hline$h r$ & & $n E q /$ liter & mmoles/liter \\
2 & Control (19)* & $43.6 \pm 0.8 \ddagger$ & $24.5 \pm 0.5$ \\
& Acidotic (21) & $79.0 \pm 1.9$ & $13.8 \pm 0.4$ \\
4 & Control (10) & $40.4 \pm 1.8$ & $26.4 \pm 0.8$ \\
& Acidotic (11) & $66.0 \pm 2.9$ & $16.8 \pm 0.4$ \\
6 & Control (19) & $40.5 \pm 1.4$ & $24.2 \pm 0.4$ \\
& Acidotic (22) & $58.1 \pm 1.4$ & $16.5 \pm 0.3$ \\
\hline
\end{tabular}

* The numbers in parentheses refer to the number of animals. $\ddagger$ Mean \pm SEM.

no statistical correlation between ammonia and glucose production for the first $6 \mathrm{hr}$, but in the rats acidotic for $48 \mathrm{hr}$, a significant correlation existed (Fig. 2).

With succinate as substrate there was also an increase in gluconeogenesis in slices from the acidotic rats ( $\mathrm{Ta}$ ble IV). The values at 2,4 , and $6 \mathrm{hr}$ are all higher than control, but there is no significant rise in gluconeogenic capacity with increasing duration of acidosis as was seen when glutamine was used as substrate. The most probable reason for this is that $180-190$ $\mu$ mole/g dry weight per $\mathrm{hr}$ represents the maximal gluconeogenic capacity of the tissue. The possibility that ammonium ions stimulated gluconeogenesis was considered, so cortical slices were incubated with either 10 mM succinate or $10 \mathrm{~mm}$ glutamine as substrate in flasks to which $\mathrm{NH}_{4} \mathrm{Cl}$ was added to a final concentration of $0.1,0.2$, or $0.5 \mathrm{mmole} / \mathrm{liter}$. All experiments were done

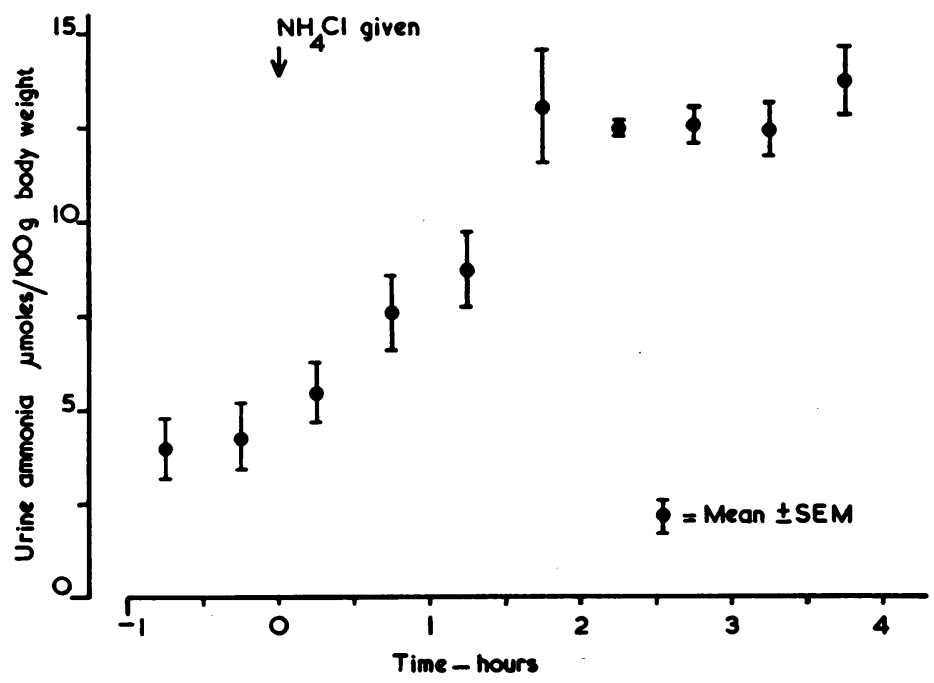

FIGURE 1 Urinary ammonia after oral administration of ammonium chloride. 
TABLE II

Glucose Production by Kidney Cortical Slices after Acidosis of Varying Duration (Substrate $10 \mathrm{mM}$ Glutamine)

\begin{tabular}{|c|c|c|c|c|c|}
\hline & \multirow[b]{2}{*}{ Control } & \multicolumn{4}{|c|}{ Duration of acidosis, $\mathrm{hr}$} \\
\hline & & 2 & 4 & 6 & 48 \\
\hline 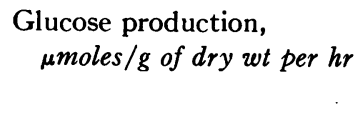 & $\begin{array}{r}72.9^{*} \\
3.6 \ddagger\end{array}$ & $\begin{array}{r}90.9 \\
3.4\end{array}$ & $\begin{array}{r}95.9 \\
5.4\end{array}$ & $\begin{array}{r}115.5 \\
5.5\end{array}$ & $\begin{array}{r}136.5 \\
6.3\end{array}$ \\
\hline $\begin{array}{c}\text { Significance of difference } \\
\text { from controls, } P \\
2 \mathrm{hr}, P \\
4 \mathrm{hr}, P \\
6 \mathrm{hr}, P\end{array}$ & $\begin{array}{l}- \\
- \\
-\end{array}$ & $\begin{array}{c}<0.005 \\
- \\
- \\
-\end{array}$ & $\begin{array}{c}<0.005 \\
\text { NS } \\
- \\
-\end{array}$ & $\begin{array}{c}<0.001 \\
<0.001 \\
<0.025 \\
-\end{array}$ & $\begin{array}{l}<0.001 \\
<0.001 \\
<0.001 \\
<0.025\end{array}$ \\
\hline
\end{tabular}

Each value represents the mean of at least 14 observations.

* Mean.

$\ddagger$ SEM.

at the same $\mathrm{pH}$. There was no stimulation of gluconeogenesis by ammonium ions (Table V).

$P E P C K$ activity. Since it was shown previously (3) that PEPCK was the key gluconeogenic enzyme stimulated by acidosis, this enzyme was assayed at the times indicated. Two assays were used: the oxaloacetate decarboxylation and the bicarbonate exchange. The latter used partly as a check on the data obtained by the former which is technically more difficult, and also because it is being used in this laboratory for further studies on the metabolic control of the increase in enzyme activity resulting from acidosis. The results of the decarboxylation assay are shown in Table VI. As early as $4 \mathrm{hr}$ after making the rats acidotic, there was a significant increase in enzyme activity. With the ex- change assay (Table VII) there is a significant increase in activity at $6 \mathrm{hr}$, and at $48 \mathrm{hr}$ this increase was still greater.

Incorporation of orotic acid $-^{s} H$ into $R N A$ (Table $V I I I)$. This was measured to see whether the increased enzyme activity was associated with increased RNA synthesis. Acidosis depressed the incorporation of orotic acid- ${ }^{3} \mathrm{H}$ into kidney cortex RNA. At $2 \mathrm{hr}$ this inhibition was marked and was less at $4 \mathrm{hr}$, but there was no significant difference between control and acidotic rats at $6 \mathrm{hr}$. The decrease in RNA synthesis shown by the decreased incorporation of orotic acid $-{ }^{8} \mathrm{H}$ into RNA is not reflected in the tissue RNA levels or the RNA : DNA ratios which remained normal throughout the $6 \mathrm{hr}$ period of acidosis (Table IX). This ex-

TABLE III

Ammonia Production by Kidney Cortical Slices after Acidosis of Varying Duration (Substrate 10 mM Glutamine)

\begin{tabular}{|c|c|c|c|c|c|}
\hline & \multirow[b]{2}{*}{ Control } & \multicolumn{4}{|c|}{ Duration of acidosis, $\mathrm{hr}$} \\
\hline & & 2 & 4 & 6 & 48 \\
\hline $\begin{array}{l}\text { Ammonia production, } \\
\mu m o l e s / g \text { of } d r y \text { wt per } h r\end{array}$ & $\begin{array}{r}688.1^{*} \\
27.9 \ddagger\end{array}$ & $\begin{array}{r}949.6 \\
14.3\end{array}$ & $\begin{array}{r}929.7 \\
41.2\end{array}$ & $\begin{array}{r}799.7 \\
30.0\end{array}$ & $\begin{array}{r}1045.1 \\
41.8\end{array}$ \\
\hline $\begin{array}{c}\text { Significance of difference } \\
\text { from controls, } P \\
2 \mathrm{hr}, P \\
4 \mathrm{hr}, P \\
6 \mathrm{hr}, P\end{array}$ & $\begin{array}{l}- \\
- \\
-\end{array}$ & $\begin{array}{c}<0.001 \\
- \\
- \\
-\end{array}$ & $\begin{array}{c}<0.001 \\
\text { NS } \\
- \\
-\end{array}$ & $\begin{array}{c}<0.02 \\
<0.02 \\
<0.025 \\
\quad-\end{array}$ & $\begin{array}{c}<0.001 \\
\text { NS } \\
\text { NS } \\
<0.001\end{array}$ \\
\hline
\end{tabular}

Each value represents the mean of 9-14 observations.

* Mean.

$\ddagger$ SEM. 


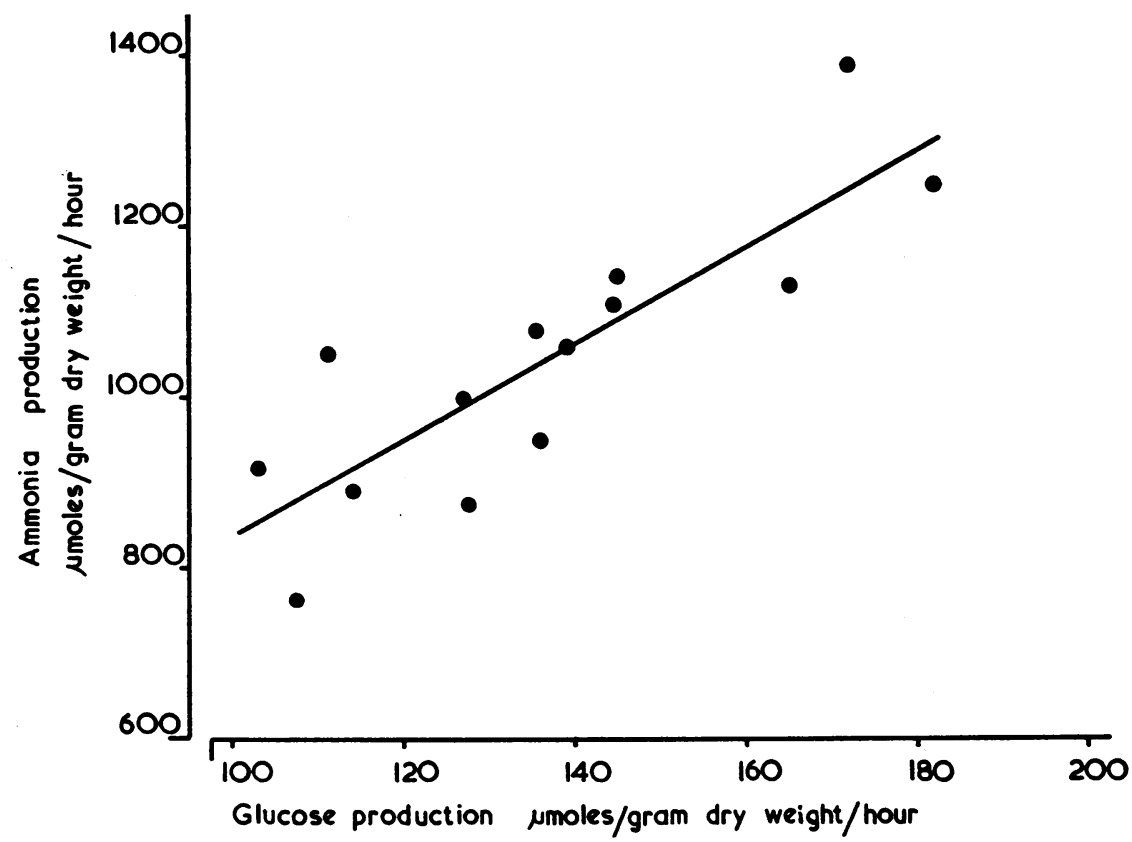

FIGURE 2 The relationship between in vitro gluconeogenesis and ammonia production in cortical slices from rats acidotic for $48 \mathrm{hr} . r=0.84 ; P<0.001$; regression equation is $y=5.6 x+280.7$.

periment was not done at $48 \mathrm{hr}$, since it has already been reported (14) that at that time there is an increase of renal RNA.

Levels of metabolic intermediates (Table $X)$. Even after $48 \mathrm{hr}$ of acidosis pyruvate and lactate were the same in control and acidotic rats, and there was no significant difference in the lactate: pyruvate ratios between control and acidotic rats at any stage. Both pyruvate and lactate tended to be higher in the more chronically acidotic rats. There was a significant decrease in $\alpha$-ketoglutarate at $2 \mathrm{hr}$, and this was still apparent in the rats which were acidotic for $48 \mathrm{hr}$. The changes in malate levels were similar to those for $\alpha$-ketoglutarate. Aspartate was significantly higher in

TABLE IV

Glucose Production by Kidney Cortical Slices after Acidosis of Varying Duration (Substrate 10 mM Sucrinate)

\begin{tabular}{lrrrr}
\hline & & \multicolumn{3}{c}{ Duration of acidosis, hr } \\
\cline { 3 - 5 } & Control & 2 & 4 & 6 \\
\hline $\begin{array}{l}\text { Glucose production, } \\
\mu m o l e s / g \text { of } d r y \text { wt per } h r\end{array}$ & $161.2^{*}$ & 191.7 & 183.2 & 190.6 \\
& $6.8^{\ddagger}$ & 5.6 & 5.1 & 6.7 \\
$\begin{array}{l}\text { Significance of difference } \\
\text { from controls, } P\end{array}$ & - & $<0.005$ & $<0.02$ & $<0.01$ \\
\hline
\end{tabular}

Each value represents the mean of 11-14 observations. * Meari.

$\mp$ SEM. the acidotic rats at 2,4 , and $6 \mathrm{hr}$, but by $48 \mathrm{hr}$ there was no difference between the two groups of animals. Phosphoenol pyruvate levels were unchanged at 2 and $4 \mathrm{hr}$, but by $6 \mathrm{hr}$ they had risen significantly in the acidotic rat. This rise was even more striking at $48 \mathrm{hr}$.

\section{DISCUSSION}

The data show that as early as $2 \mathrm{hr}$ after $\mathrm{NH}_{4} \mathrm{Cl}$, rats already have a severe metabolic acidosis, and in response to this, there is increased urinary excretion of ammonia. Rats were not sacrificed earlier than $2 \mathrm{hr}$ after the acid load, but judging from the increase in urinary ammonia which is apparent $1 \frac{1}{2} \mathrm{hr}$ after ammonium chlo-

TABLE V

Effect of Varying Concentrations of $\mathrm{NH}_{4}{ }^{+}$ on In Vitro Gluconeogenesis

\begin{tabular}{|c|c|c|}
\hline \multirow[b]{2}{*}{$\begin{array}{c}\mathrm{NH}_{4} \mathrm{Cl} \\
\text { concentration }\end{array}$} & \multicolumn{2}{|c|}{ Glucose produced } \\
\hline & $\begin{array}{l}\text { Substrate } 10 \mathrm{~mm} \\
\text { succinate }\end{array}$ & $\begin{array}{l}\text { Substrate } 10 \mathrm{~mm} \\
\text { glutamine }\end{array}$ \\
\hline mmoles/liter & \multicolumn{2}{|c|}{$\mu$ moles $/ g$ of dry wt per $h r$} \\
\hline 0 & $150.5 \pm 11.8^{*}(6) \ddagger$ & $83.4 \pm 8.4$ \\
\hline 0.1 & $161.4 \pm 9.2$ & $88.4 \pm 11.9$ \\
\hline 0.2 & $157.1 \pm 6.4$ & $83.5 \pm 6.6$ \\
\hline 0.5 & $145.4 \pm 5.5$ & $72.8 \pm 9.2$ \\
\hline
\end{tabular}

* Mean ISEM.

$\ddagger$ No. of observations.

Early Renal Response to Metabolic Acidosis 
TABLE VI

PEPCK Activity in Kidney Cortex from Rats with $\mathrm{NH}_{4} \mathrm{Cl}$ Induced Acidosis of Different Duration (Decarboxylation Assay)

\begin{tabular}{cccc}
\hline $\begin{array}{c}\text { Duration of } \\
\text { acidosis }\end{array}$ & Group & $\begin{array}{c}\text { No. of } \\
\text { rats }\end{array}$ & PEPCK* \\
\hline$h r$ & & & \\
2 & Control & 6 & $97.7 \pm 12.3 \ddagger$ \\
& Acidotic & 8 & $90.3 \pm 7.2$ \\
4 & Control & 6 & $100.5 \pm 8.7$ \\
& Acidotic & 9 & $154.6 \pm 12.7$
\end{tabular}

* PEPCK activity in nanomoles of PEP formed per minute per milligram of protein.

$\ddagger$ Mean \pm SEM.

ride, there must be a significant degree of acidosis even earlier than $2 \mathrm{hr}$. The rise in urinary ammonia at $1 \frac{1}{2} \mathrm{hr}$ indicates an increase in renal ammonia production.

It has been shown that glutamine is the major source of urinary ammonia, and in dogs acidotic for 3 days the amide and amino groups of glutamine contribute 35$50 \%$ and $16-25 \%$ respectively of the urine ammonia (15). There are two possible pathways by which glutamine may contribute to renal ammonia. Glutamine may be deamidated to form glutamate and ammonia (enzyme-glutaminase I) or alternatively, the amino group may be removed by transamination with the resultant formation of $\alpha$-ketoglutaramate and an amino acid. The $\alpha$-ketoglutaramate is deamidated to give $\alpha$-ketoglutarate and ammonia by a highly active enzyme $\omega$-amidase. The glutamine transaminase and $\omega$-amidase are collectively referred to as the glutaminase II system.

\section{TABLE VII}

PEPCK Activity in Kidney Cortex from Rats with $\mathrm{NH}_{4} \mathrm{Cl}$ Induced Acidosis of Different Duration Bicarbonate ${ }^{14} C$ Exchange Assay

\begin{tabular}{clrr}
\hline $\begin{array}{c}\text { Duration of } \\
\text { acidosis }\end{array}$ & Group & $\begin{array}{c}\text { No. of } \\
\text { rats }\end{array}$ & \multicolumn{1}{c}{$\begin{array}{c}\text { PEPCK } \\
\text { activity* }\end{array}$} \\
\hline$h r$ & & & \\
2 & Control & 5 & $55,630 \pm 4,980 \ddagger$ \\
& Acidotic & 5 & $60,258 \pm 17,550$ \\
4 & Control & 5 & $64,812 \pm 2,307$ \\
& Acidotic & 5 & $65,998 \pm 4,524$ \\
6 & Control & 15 & $49,731 \pm 4,049$ \\
& Acidotic & 15 & $65,472 \pm 4,237$ \\
& Control & 5 & $51,228 \pm 2,460$ \\
& Acidotic & 4 & $114,599 \pm 7,605$
\end{tabular}

* PEPCK activity in counts per minute of ${ }^{14} \mathrm{HCO}_{3}^{-}$incorporated into malate $/ 100 \mathrm{mg}$ of protein per $4 \mathrm{~min}$ of assay. $\ddagger$ Mean \pm SEM.
TABLE VIII

Incorporation of Orotic Acid- ${ }^{3} \mathrm{H}$ in RNA of Rat Kidney Cortex after Different Duration of Acidosis

\begin{tabular}{clcc}
\hline $\begin{array}{c}\text { Duration of } \\
\text { acidosis }\end{array}$ & Group & $\begin{array}{c}\text { No. of } \\
\text { rats }\end{array}$ & $\begin{array}{c}\text { Orotic acid-s } \mathrm{H} \\
\text { uptake into RNA }\end{array}$ \\
\hline $\mathrm{hr}$ & & & $c p m / m g$ RNA \\
2 & Control & 7 & $23,759.3 \pm 1,619.4^{*}$ \\
& Acidotic & 5 & $5,315.5 \pm 597.0$ \\
4 & Control & 5 & $24,455.0 \pm 1,097.0$ \\
& Acidotic & 6 & $15,417.1 \pm 1,116.8$ \\
6 & Control & 5 & $31,704.8 \pm 5,798.7$ \\
& Acidotic & 6 & $21,282.8 \pm 3,568.4$ \\
\hline
\end{tabular}

* Mean \pm SEM.

Enhanced gluconeogenesis in response to acidosis was considered important in that, at least in the rat, it served to remove the glutamate formed as a product of the glutaminase I reaction since glutamate itself inhibited the enzyme $(4,16)$.

The present data show that increased renal gluconeogenesis is a very early response to metabolic acidosis, and as such would facilitate the early increase in renal ammonia production. There is increased gluconeogenesis in vitro from both glutamine and succinate, and the pattern of metabolic intermediate suggests that there is increased gluconeogenesis in vivo. It is known that renal glutamate levels decrease rapidly with acidosis (15) and the fall in $\alpha$-ketoglutarate and malate shown here are in keeipng with increased flux along the gluconeogenesis pathway. Levels of phosphoenolpyruvate (PEP) did not rise until $6 \mathrm{hr}$ after acidosis, but since the level of any metabolic intermediate is a reflection of the activities of enzymes before and after it in a given pathway, the normal PEP levels do not preclude the supposition that there is increased gluconeogenesis in

\section{TABLE IX}

RNA and RNA/DNA Ratios in Kidney Cortex of Rats after Acidosis of Different Duration

\begin{tabular}{ccrcc}
\hline $\begin{array}{c}\text { Duration } \\
\text { of } \\
\text { acidosis }\end{array}$ & Group & $\begin{array}{c}\text { No. of } \\
\text { rats }\end{array}$ & RNA & RNA/DNA \\
\hline$h r$ & & & $m g / g$ cortex & \\
2 & Control & 10 & $5.09 \pm 0.18^{*}$ & $1.17 \pm 0.04$ \\
& Acidotic & 9 & $4.80 \pm 0.19$ & $1.05 \pm 0.04$ \\
4 & Control & 10 & $5.18 \pm 0.07$ & $1.11 \pm 0.05$ \\
& Acidotic & 10 & $5.10 \pm 0.10$ & $1.15 \pm 0.08$ \\
6 & Control & 10 & $4.93 \pm 0.26$ & $1.10 \pm 0.06$ \\
& Acidotic & 9 & $5.07 \pm 0.29$ & $1.14 \pm 0.04$ \\
\hline
\end{tabular}

* Mean \pm SEM. 
TABLE X

Levels of Metabolic Intermediates in Whole Kidneys of Rats with $\mathrm{NH}_{4} \mathrm{Cl}$-Induced Acidosis of Different Duration

\begin{tabular}{llcccc}
\hline \multirow{2}{*}{ Intermediate } & & \multicolumn{4}{c}{ Duration of acidosis, hr } \\
\cline { 3 - 5 } Pyruvate & Group & 2 & 4 & 6 \\
& & \multicolumn{2}{c}{ nmoles $/$ 100 mg of protein } \\
Lactate & Control & $21.5 \pm 5.5^{*}$ & $19.5 \pm 3.1$ & $23.1 \pm 3.1$ & $35.9 \pm 5.5$ \\
& Acidotic & $24.1 \pm 2.7$ & $19.6 \pm 2.1$ & $27.8 \pm 2.4$ & $33.5 \pm 3.6$ \\
Lactate/Pyruvate & Control & $333.7 \pm 51.1$ & $270.6 \pm 34.3$ & $303.9 \pm 31.5$ & $619.8 \pm 170.8$ \\
& Acidotic & $326.1 \pm 52.6$ & $295.3 \pm 46.7$ & $385.6 \pm 76.7$ & $419.4 \pm 99.3$ \\
$\alpha$-ketoglutarate & Control & $15.1 \pm 1.6$ & $14.9 \pm 2.1$ & $13.6 \pm 0.9$ & $15.9 \pm 2.5$ \\
& Acidotic & $13.3 \pm 1.7$ & $16.2 \pm 3.4$ & $13.6 \pm 1.8$ & $16.9 \pm 1.4$ \\
Malate & Control & $120.6 \pm 25.1$ & $158.9 \pm 22.0$ & $149.6 \pm 12.6$ & $199.0 \pm 31.0$ \\
& Acidotic & $55.4 \pm 5.4$ & $39.8 \pm 2.1$ & $42.1 \pm 4.1$ & $84.3 \pm 8.0$ \\
Asparatate & Control & $126.2 \pm 16.7$ & $110.5 \pm 15.6$ & $125.0 \pm 11.1$ & $118.5 \pm 8.8$ \\
& Acidotic & $91.3 \pm 7.1$ & $80.1 \pm 11.0$ & $74.8 \pm 3.8$ & $91.9 \pm 7.7$ \\
Phosphoenol pyruvate & Control & $580.9 \pm 48.9$ & $623.7 \pm 42.5$ & $559.5 \pm 35.0$ & $664.6 \pm 25.3$ \\
& Acidotic & $793.7 \pm 39.1$ & $846.8 \pm 15.1$ & $751.6 \pm 37.2$ & $646.7 \pm 33.2$
\end{tabular}

Each value represents the mean of at least five rats except control lactate at $48 \mathrm{hr}$ where only four ratswere used.

* Mean 土SEM.

vivo as early as $2 \mathrm{hr}$ after ammonium chloride was given. Indeed, in spite of increased gluconeogenesis glucose-6-phosphate which is distal to PEP in the gluconeogenic sequence, does not show any change even after $48 \mathrm{hr}$ of acidosis (Alleyne and Flores, unpublished data). This probably indicates that there is another rate-limiting enzyme between PEP and glucose-6-phosphate. Goodman, Fuisz, and Cahill (4) reported that in vitro gluconeogenesis was not increased until $12 \mathrm{hr}$ after induction of acidosis. The reason for this is not clear but it is possible that administration of ammonium chloride in dextrose may have suppressed the early gluconeogenic response in their animals since glucose feeding depresses renal PEPCK activity (Alleyne, unpublished data).

It was suggested previously that PEPCK was the controlling enzyme in the gluconeogenic response to acidosis (3). Both methods of enzyme assay show early increases in PEPCK activity. The decarboxylation assay is the more physiologically important here since it is via the decarboxylation of oxaloacetate that gluconeogenesis takes place. In any case both assays show an increased PEPCK activity 4-6 hr after induction of acidosis.

RNA metabolism was investigated to see whether the increase in enzyme activity was associated with enhanced RNA and presumably new protein synthesis. If uptake of orotic acid- ${ }^{-8} \mathrm{H}$ into RNA can be equated with
RNA synthesis, it can be said that there was decreased RNA synthesis up to $4 \mathrm{hr}$ after the acid load. The fact that RNA levels and RNA : DNA ratio did not change is in keeping with the observation that in the rat kidney hypertrophied as a result of contralateral nephrectomy or acidosis, there is no change in renal RNA until after 24 and $36 \mathrm{hr}$ (14). The depression of RNA synthesis in the presence of enhanced enzyme activity may indicate that there is a small separate fraction of RNA which codes for the PEPCK protein, is not affected by the general depression of RNA synthesis, and is undetectable since it is relatively small. Alternatively, the increased enzyme activity may not denote increased enzyme synthesis, but there may be activation of a previously inactive form of the enzyme. Such a change has been suggested for liver PEPCK after tryptophan injection (17). The rise in enzyme activity $4 \mathrm{hr}$ after $\mathrm{NH} 4 \mathrm{Cl}$ is rapid, but not surprising since Lardy, Foster, Shrago, and Ray (18) have shown a twofold increase in liver PEPCK 3-4 hr after injection of a single dose of hydrocortisone.

Although both gluconeogenesis and ammonia production were increased as part of the early response to metabolic acidosis, these two processes were apparently not as closely linked as in the more chronically acidotic rat. In rats acidotic for $48 \mathrm{hr}$, it has been shown that PEPCK activity is well correlated with urinary ammonia (3) and the present experiments show a good corre- 
lation between in vitro glucose and ammonia production. $2 \mathrm{hr}$ after the acid load, in vitro ammonia production rose, but then declined significantly; on the contrary glucose production rose steadily. In addition, there was no statistical correlation between in vitro glucose and ammonia production in these early stages. These observations led to the speculation that it was the increased renal ammonia which was the stimulus for the increased gluconeogenesis. The experiments in which varying concentrations of ammonium chloride were tried in vitro did not give any support to this thesis.

It was suggested that the increased renal gluconeogenesis evoked by metabolic acidosis was important for the removal of glutamate which, although it was the product, inhibited the glutaminase I enzyme (4). There is possibly evidence here to show that this need not be the major role for the early gluconeogenic response to acidosis, and glutamine may be metabolized significantly through the glutaminase II pathway with $\alpha$-ketoglutarate the product of the reaction being removed by gluconeogenesis.

Aspartate is the transamination product of oxaloacetate, so the early rise in aspartate levels may mean that there was an increase in oxaloacetate transamination. If this were so, we might expect that a rise in aspartate would be accompanied by a fall in oxaloacetate levels. Oxaloacetate levels in kidney are too low to be measured accurately, but it is possible to make some deductions about them from a knowledge of the levels and ratios of other intermediates. The lactate and pyruvate levels as well as the lactate pyruvate ratios are unchanged, thus, at least in the extramitochondrial compartment where the glutaminase II system is probably located (19), malate: oxaloacetate ratios must also be unchanged (20). Since malate levels are decreased, oxaloacetate levels must be decreased similarly, so that in the presence of the known increased glutamine metabolism (21), a rise in aspartate and a fall in oxaloacetate occur. Thus it is feasible to suggest that glutamine may be the amino donor to oxaloacetate with resulting formation of aspartate. If this did occur there would be increased formation of the deamination production of glutamine- $\alpha$-ketoglutaramate which is readily deamidated by the $\omega$-amidase enzyme. Thus there might be increased ammonia production along the glutaminase II pathway at this stage. The assumption inherent in this analysis is that the measured levels of aspartate and malate are a reflection of their levels in the cytoplasm, but this is not unreasonable since they both pass freely across the mitochondrial membrane. Stone and Pitts (22) have demonstrated that in the chronically acidotic dog the glutaminase II system may be quantitatively significant in ammonia production.
It has been suggested that the increased metabolism of glutamine is the stimulus to increased gluconeogenesis (21), but this is unlikely in view of the demonstration that with in vitro reduction in $\mathrm{pH}$ there was increased gluconeogenesis with substrates other than glutamine (23). Recently also it has been shown that 3',5'-AMP may stimulate gluconeogenesis and ammonia production in vitro (24), but there are as yet no data to suggest that this may be the stimulus which increases gluconeogenesis and ammonia production in acidosis. A further proposal has been that there is a change in redox state of pyridine nucleotides in the kidney, and this may play a role in the increased ammonia production in response to acidosis (25).

The experiments reported here do not make it clear whether the metabolic events described are caused entirely by the hydrogen ion or whether there is some other effector stimulus or stimuli such as those mentioned above. It is very probable however that this approach of measuring important metabolic intermediates and correlating experiments in vivo and in vitro will ultimately detect the precise stimulus for the metabolic events which follow acidosis.

\section{ACKNOWLEDGMENTS}

I am grateful to Professor J. C. Waterlow, Director of this Unit, for his advice and constant encouragement. I am especially indebted to Dr. Hernando Flores, David Millward, Harvey Besterman, and Claudette Cousins for fruitful discussions and technical help.

\section{REFERENCES}

1. Sartorius, O. W., J. C. Roemmelt, and R. F. Pitts. 1949. The renal regulation of acid-base balance in man. IV. The nature of the renal compensations in ammonium chloride acidosis. J. Clin. Invest. 28: 423.

2. Alleyne, G. A. O. 1968. Concentrations of metabolic intermediates in kidneys of rats with metabolic acidosis. Nature (London). 217: 847.

3. Alleyne, G. A. O., and G. H. Scullard. 1969. Renal metabolic response to acid base changes. I. Enzymatic control of ammoniagenesis in the rat. J. Clin. Invest. 48: 364 .

4. Goodman, A. D., R. E. Fuisz, and G. F. Cahill, Jr. 1966. Renal gluconeogenesis in acidosis, alkalosis and potassium deficiency: its possible role in regulation of renal ammonia production. J. Clin. Invest. 45: 612 .

5. Goorno, W. E., F. C. Rector, Jr., and D. W. Seldin. 1967. Relation of renal gluconeogenesis to ammonia production in the dog and rat. Amer. J. Physiol. 213: 969.

6. Deutsch, W. 1936. An improvement of Warburg's method for cutting tissue slices for respiratory experiments. J. Physiol. (London). 87: 56P.

7. Bergmeyer, H. U. 1965. Methods of enzymatic analysis. Academic Press Inc., New York.

8. Munro, H. N., and A. Fleck. 1969. Analysis for nitrogenous constituents. In Mammalian Protein Metabolism. H. N. Munro and J. B. Allison, editors. Academic Press Inc., New York. 3: 423. 
9. Nordie, R. C., and H. A. Lardy. 1963. Mammalian liver phosphoenolpyruvate carboxykinase activities. J. Biol. Chem. 238: 2259.

10. Chang, H.-C., and M. D. Lane. 1966. The enzymatic carboxylation of phosphoenolpyruvate. II. Purification and properties of liver mitochondrial phosphoenolpyruvate carboxykinase. J. Biol. Chem. 241: 2413.

11. Lowry, O. H., N. J. Rosebrough, A. L. Farr, and R. J. Randall. 1951. Protein measurement with the Folin phenol reagent. J. Biol. Chem. 193: 265.

12. McCullough, H. 1967. The determination of ammonia in whole blood by a direct colorimetric method. Clin. Chim. Acta. $17: 297$.

13. Huggett, A. St. G., and D. A. Nixon. 1957. Use of glucose oxidase, perioxidase, and $o$-dianisidine in determination of blood and urinary glucose. Lancet. 2: 368.

14. Bignall, M. C., O. Elebute, and W. D. Lotspeich. 1968. Renal protein and ammonia biochemistry in $\mathrm{NH}_{4} \mathrm{Cl}$ acidosis and after uninephrectomy. Amer. J. Physiol. 215: 289.

15. Pitts, R. F., L. A. Pilkington, and J. C. M. de Haas. 1965. $\mathrm{N}^{15}$ tracer studies on the origin of urinary ammonia in the acidotic dog, with notes on the enzymatic synthesis of labelled glutamic acid and glutamins. J. Clin. Invest. 44: 731.

16. Goldstein, L., and J. H. Copenhaver, Jr. 1960. Relation of glutaminase $\mathrm{i}$ activity to glutamic acid concentration in the rat kidney. Amer. J. Physiol. 198: 227.
17. Foster, D. O., H. A. Lardy, P. D. Ray, and J. B. Johnston. 1967. Alteration of rat liver phosphoenolpyruvate carboxykinase activity by L-tryptophan in vivo and metals in vitro. Biochemistry. $6: 2120$.

18. Lardy, H. A., D. O. Foster, E. Shrago, and P. D. Ray. 1964. Metabolic and hormonal regulation of phosphopyruvate synthesis. Advan. Enzyme Regul. 2: 39.

19. De Duve, C., R. Wattiaux, and P. Baudhuin. 1962. Distribution of enzymes between subcellular fractions in animal tissues. Advan. Enzymol. 24: 291.

20. Williamson, D. H., P. Lund, and H. A. Krebs. 1966. The redox state of free nicotinamide-adenine dinucleotide in the cytoplasm and mitochondria of rat liver. Biochem. J. $103: 514$.

21. Simpson, D. P., and D. J. Sherrard. 1969. Regulation of glutamine metabolism in vitro by bicarbonate ion and $\mathrm{pH}$. J. Clin. Invest. 48: 1088.

22. Stone, W. J., and R. F. Pitts. 1967. Pathways of ammonia metabolism in the intact functioning kidney of the dog. J. Clin. Invest. 46: 1141.

23. Kamm, D. E., R. E. Fuisz, A. D. Goodman, and G. F. Cahill, Jr. 1969. Acid-base alterations and renal gluconeogenesis: effect of $\mathrm{pH}$, bicarbonate concentration and $\mathrm{PCO}_{2}$. J. Clin. Invest. 46: 1172.

24. Pagliara, A. S., and A. D. Goodman. 1969. Effect of adenosine $3^{\prime}, 5^{\prime}$-monophosphate on production of glucose and ammonia by renal cortex. J. Clin. Invest. 48: 1408.

25. Preuss, H. G. 1968. Pyridine nucleotides in renal ammonia metabolism. J. Lab. Clin. Med. 72: 370. 